\title{
Strategies for Promoting Steelmaking Slag Resourcezation in Taiwan
}

\author{
Ching-Jung Chang \\ Department of Construction Management, Chung Hua University, Hsinchu 30012, Taiwan
}

\begin{abstract}
Because of the world ever-growing pursuit of economic growth, natural resources have been overly exploited and squandered. Such actions have created a negative effect on the environment and led to resource depletion. These problems subsequently garnered the government attention for waste reuse, in which they began to promote sustainable circulation and reuse of resources to lower natural resource consumptions. Accordingly, the concept of the "3 R's," namely, reduce, recycle, and reuse was introduced. However, the said concept merely adopts a unidirectional, cradle-to-grave-based treatment and fails to consider the effects of waste on the economy and society. Taiwan produces approximately 20 million tonne s of waste annually, roughly $40 \%$ of which are slags. The illegal dumping and burying of slags have negatively influenced Taiwan's environment, economy, and society. Thus, the present study revolutionized the 3R concept by introducing the cradle to cradle concept. Producers are recommended to consider product features and slag usage options during the steelmaking process. Transparent productions, effective management, scientific treatments, and systematic inspections are employed to bring slags into industrial circulations, facilitating the recycling and reuse of resources.
\end{abstract}

\section{Introduction}

The steel industry is the mother of all industries and the foundation of national development. However, the steelmaking process results in a significant amount of waste, known as slag waste. In 2014, steelmaking plants around the world created approximately 160 million tonnes of slags [1], in which Taiwan accounted for approximately 7.7 million tonnes of such slags annually. To achieve slag "resourcezation" (i.e., make slags into resources), one must first understand slag properties and determine what they are to be used before implementing the corresponding reuse technologies. Such endeavors will facilitate the goals of waste resourcezation, create market-based resource circulations, reduce the negative impact of slags on the ecosystem, and elevate industry operation efficiencies.

Because different raw materials and steelmaking methods are used during the different stages of the steelmaking process, they create different slag compositions and properties. This leads to significantly different resource reuse options. Concerning slags, they are divided into blast furnace (BF) slags, basic oxygen furnace (BOF) slags, desulfurization slags, electric arc furnace (EAF) oxidizing slags, and EAF reductive slags. $\mathrm{BF}, \mathrm{BOF}$, and desulfurization slags are byproducts of the continuous steelmaking process, whereas oxidizing and reductive slags are those of the EAF steelmaking process.

When smelting is performed in a blast furnace (in an integrated steeling mills) during the steelmaking process, materials such as limestones are added as fusing agents to allow iron ore and coke impurities to synthesize, forming slags. Because slags have a relatively smaller specific gravity, they can be separated from molten iron. When slags created from the blast furnace process are cooled, they produce a solid matter called BF slags. By cooling high-temperature BF slags in liquid state using different cooling methods, air-cooled BF slag and ground granulated $\mathrm{BF}$ slags can be produced. Because molten iron created from BF-based smelting contains sulfur, it is transferred to torpedo to be desulfurized by desulfurization agents. The resulting product is naturally cooled to form a finely grained solid called desulfurization slags. By contrast, when smelting is performed in a converter during the steelmaking process, it creates Basic Oxygen Furnace slag (BOF slags). Because the said process involves making iron ores into iron first before making them into steel, it is called continuous steelmaking.

For electric arc furnace steelmaking, the primary raw materials used are recycled scrap steel and iron. Regarding slags created from the EAF steelmaking process, they comprise EAF oxidizing slags (created prior to the steelmaking process) and EAF reductive slags (created after the steelmaking process). Because the sources of recycled scrap steel and iron differ, and that minerals added during the steelmaking process vary, each batch of slags created exhibits significantly different chemical composition and quality.

Every year, steelmaking plants discharge million tonnes of toxic substances into the natural environment, consume and waste countless resources, produce innumerable waste, destroy the global cultural diversity, 
and jeopardize biodiversity [3]. To make up for these mistakes, government agencies, researches and environmentalists proposed the concept of the 3 R's. However, such a concept did not eliminate the discharge of toxic substances or the consumption of resources and merely extended product life cycles by two or three-fold. The end result remained the same: cradle to grave.

Thus, Professor Braungart put forward a proactive solution, positing that reduction in damages created will not make the world a better place and that the concept of waste does not exist in nature. In essence, all substances should be viewed as nutrients that can be returned to nature. To achieve this ideal, he asked designers to consider the methods to transition resources used in product production into the beginning of the next cycle, and maintained that designers should do this as early as the product design stage. He termed this idea "cradle to cradle".

The paper examined the promotional strategies employed to resourcize various types of steelmaking slags, integrated relevant treatment technologies, and adopted the cradle to cradle concept to achieve the goals of slag resourcezation and improve slag recycling. This study put forward what the various parties of the steelmaking process could do to manage slags and facilitate the use of slags in the industrial "metabolic cycle." The study results may serve as a reference to producers, consumers, and the government when implementing environmental protection strategies.

\section{Slag classifications and properties}

Waste is defined generally as an unusable substance or one of no value [4]. As environmental protection awareness becomes increasingly important and natural resources become increasingly scarce, identifying approaches to utilize reprocessing procedure and proper planning to properly reuse waste, convert identified waste into recycled resources. Transform waste into industrial materials are crucial to effectively lowering the misuse or disposal of waste and thereby diminishing its negative impact on the environment. Because of the numerous types of waste that exist and that their disposal or retreatments differ. For waste reuse to be feasible, the following conditions must be met: the waste materials must be able to stably serve as alternatives of materials demanded by the market, and the demand for waste materials must be greater than their supply. When these two conditions are met can an incentive for using waste be created and waste quantity and storage be reduced.

Slags contain silicates and ferrite compounds made of $\mathrm{SiO}_{2}, \mathrm{Al}_{2} \mathrm{O}_{3}, \mathrm{CaO}, \mathrm{MgO}$, and $\mathrm{Fe}_{2} \mathrm{O}_{3}$. Because slags have a chemical composition similar to that of cement, they should primarily be used as raw cement materials and/or cement replacements in cement-related applications and as backfill and/or aggregate replacements in civil engineering-related applications. Slags are divided into six categories according to the steelmaking process employed and the resulting slags produced. The slag production processes and properties are explained as follows:

\section{(A) Slags produced from continuous steelmaking plants}

\section{A.1. Blast furnace slags}

BF slag is formed in a blast furnace with molten iron from iron ore, once removed from the furnace, are subject to further processing to form a crystalline aggregate or ground blast furnace slag.

\section{A.1.1. Air-cooled BF slags}

Air-cooled BF slags, cooled naturally by air and formed form a crystalline aggregate, particle size of up to several meters [5]. Because high-temperature liquids and flowing, they envelop air during the cooling process. Once cooled, they show a porous and uneven surface. They do not contain harmful substances such as heavy metals and dioxin.

\section{A.1.2. Ground granulated BF slags}

Ground granulated BF slags are created via a high-pressure water quenching process, account for approximately $95 \%$ of all BF slags, and display hydrate cementation characteristics. The said slags are ground into ground granulated furnace powder, which is mixed with Portland cement to form Portland BF cement.

\section{A.2. Basic oxygen furnace slags}

Molten iron created in the $\mathrm{BF}$ is transferred to converter, in which raw materials such as limestones are added as fusing agents to remove molten iron impurities during the molten steel blowing process, forming molten steel. The slags created from the aforementioned process are BOF slags. BOF slags consist primarily of chemical compounds $\mathrm{CaO}, \mathrm{Fe}_{2} \mathrm{O}_{3}, \mathrm{SiO}_{2}$, and $\mathrm{MgO}$, and chemical stability tests showed that they are nontoxic and do not contain dioxin.

\section{A.3. Desulfurization slags}

Molten iron created from smelting in a BF contains sulfur content. The molten iron is subsequently transferred to the torpedo to be desulfurized by desulfurization agents. Once discharged from the torpedo, the slags undergo natural cooling and form finely grained solid matters called "desulfurization slags."

\section{(B) EAF slags}

The primary raw materials used in steelmaking are scrap steel and iron. Following a smelting reaction, most nonferrous metals and added auxiliary raw materials create EAF slags. Concerning EAFs, they are primarily made of three artificial graphite electrodes, a furnace ceiling, and a furnace body. When charged with electric 
current, the graphite electrodes generate electric arcs that measure at least $1,600^{\circ} \mathrm{C}$, melting scrap steel and iron and completing the steelmaking process. Steelmaking operations are divided in batches and each batch normally runs $1.5-3 \mathrm{hr}$. Regarding the smelting process, it is divided into three stages, which are the melting stage, the oxidation stage, and the reduction stage. The slags created during the aforementioned stages are classified as oxidizing and reductive slags, as explained below:

\section{B.1. Oxidizing slags}

Scrap steel melted by electric arcs becomes molten steel. The recycling of scrap steel is a rather complex process, in which molten steel impurities have to be oxidized to turn into liquid-state or gas-state oxides and high-pressure oxygen has to be added to accelerate the oxidation effect. The goal is to expose the molten steel impurities to oxygen to form oxides. Slags created during this process are called oxidizing slags, which have a rough shape and resemble natural igneous rocks. Oxidizing slags are primarily made of $\mathrm{SiO}_{2}, \mathrm{Al}_{2} \mathrm{O}_{3}, \mathrm{Fe}_{2} \mathrm{O}_{3}, \mathrm{CaO}, \mathrm{MgO}$, and $\mathrm{S}$ and have a metal content of approximately $50 \%$, in which $\mathrm{Fe}_{2} \mathrm{O}_{3}$ and $\mathrm{Al}_{2} \mathrm{O}_{3}$ account for the highest ratio.

\section{B.2. Reductive slags}

To prevent molten steel from containing too much oxides and affecting steel quality, reducing agents such as siliceous ores, ferromanganese, cokes, and quicklime are added to control the motel steel quality. The main objective is to induce a reaction with oxides to facilitate deoxygenation and desulfurization. Slags produced from this stage are called reductive slags. Reductive slags have a small powder-like appearance and are grayish white in color. Reductive slags are mostly made of $\mathrm{CaO}$ (approximately 48\%), $\mathrm{SiO}_{2}$ (approximately 22\%-29\%), $\mathrm{Al}_{2} \mathrm{O}_{3}$ (approximately 14\%-18\%), and $\mathrm{MgO}$.

\section{Cradle to cradle}

The companies always set economic growth as the ultimate goal of their countries. Accordingly, the focus of product designs and manufacturing has been to identify ways to deliver products to consumers quickly and inexpensively. Issues such as product life cycles and the negative impact of products on the environment were ignored [3]. Natural resources were used for unidirectional, cradle-to-grave-based product development, in which the processes involved processing resources, manufacturing products, using resources, disposing resources, and polluting the environment. In response to the said problems, the 3 R's (i.e., reduce, recycle, and reuse) were introduced. However, such methods were overly passive and did not solve the problem at the core. Strategies that emphasized reduction and recycling merely extended product life cycles and reduced usage. By contrast, Professor Braungart put forward the concept of "cradle to cradle" in 2002, contending that the idea of diminishing damages made to the environment is overly naive, and that such plans to save the Earth's natural environment would fail. He proposed a proactive solution, which focused not on repairing the damages created by industrial productions, but rather on learning how to recycle sustainably.

In Professor Braungart cradle to cradle analysis, the Earth is presumed to have two distinct metabolisms [3,6,7], namely, a biological metabolism and an industrial metabolism, and the following three basic principles are in effect: (1) view waste as food (every substance is the nutrient for another substance); (2) use existing solar power; and (3) respect diversity (i.e., biodiversity, concept diversity, and cultural diversity).

\subsection{Two distinct metabolisms}

\subsubsection{Biological metabolism}

The concept of waste does not exist in nature. For example, flowers and fruits of cherry trees that fall to the ground return to the soil and become nutrients in the ecosystem, in which nothing is wasted. Similarly, plants that die at the end of their life cycle decompose in the soil and serve as nutrients for the ecosystem to circulate.

\subsubsection{Industrial metabolism/circulation}

Designers who think about how different raw materials can be introduced to different circulations during the product development stages will allow the materials to retain their original properties and even achieve "upcycling." Because industrial products normally cannot decompose naturally, they should be used in industrial circulations, in which they are recycled and remade into valuable industrial nutrients for subsequent use.

\subsection{Three basic principles}

1. Waste is food: Every substance in nature is the nutrient for another substance. Similarly, industrial products should be upcycled.

2. Use existing solar power: Reduction in resource usage does not prevent the creation of waste or the consumption of limited energy-generation resources such as coals, petroleum, and nuclear power-related resources. By converting natural energy resources such as the Sun and winds into power, nature, the Earth, and the Earth's resources can be protected.

3. Respect diversity: Respect for biodiversity, material diversity, and cultural diversity should be practiced prior to designing and producing products. Sustainable development should be in line with local conditions, in which local materials, culture, and ecology are accounted for during product developments. To truly achieve sustainability, product manufacturers must not be short-sighted by favoring the use of cheaper energy resources and not taking into account future treatment costs.

Ecological efficiency is only used in the context of 
product life cycles, in which the effects of the various stages of products on the environment are assessed and the emphasis on pollution reduction is made. Professor Braungart argued that merely improving ecological efficiency is insufficient [8] as this only makes the matter "less bad" but not better. By contrast, cradle to cradle involves putting eco-effectiveness into practice. Such a practice involves implementing positive, step-by-step procedures rather than adopting unrealistic methods aimed to achieve perfection in a single attempt.

\section{Analysis of slag strategies}

In Taiwan, slag users having a lack of expertise and intransparent slag usage, producers implementing loose management, managers lacking complete verification systems, related units treating slags as waste and burying them or throwing them away. Companies misusing slags have resulted in the general public and engineering units misunderstanding of slags, making the promotion of slag resourcezation difficult. Therefore, the paper implemented the circulation-oriented concept of cradle to cradle, in which slags were treated as industry nutrients and the chemical and engineering properties of the different types of slags were analyzed to determine their respective resourcezation triage strategies. The goal was to allow the slags to become a part of the industrial metabolism. By treating toxic substances and making them into industrial nutrients, not only are the use of resources reduced, but the toxic substances are upcycled, enabling slags to be effectively reused and remain in closed industrial circulations.

With respect to sustainable slag developments, three dimensions are considered: (1) Economic dimension (i.e., balance): Slags are upcycled to allow them to be sold at a low price and used as replacements of natural resources; (2) Social dimension (i.e., sustainability): Users are provided with safe slags that they can use at ease; and (3) Environmental dimension (i.e., balance): Slags are used as replacements of engineering materials without polluting the environment. To achieve the aforementioned objectives, properties of the different slags and their usage potentials have to be identified, the annual output of various slags as well as users' demands for such slags have to be obtained, the market in which the slags can be used as alternative materials demanded by the market (in which the demand for the slags have to be greater than their supply) have to be determined, the amount of slags eliminated and where they are disposed have to be made transparent, and government policies have to be complied and promoted, in which producers are asked to reach a consensus.

To successfully promote slag reuse, diversified strategies will be implemented. For example, civil engineering and/or cement-related producers will be recruited to convert slags into those featuring specifications demanded by users. Next, in accordance with government laws and regulations, complete and transparent product channels will be introduced to ensure that slags are treated by designated units and that their usage and disposal locations are controlled.

\subsection{Properties of the different slags}

\subsubsection{Blast furnace slag}

A. Air-cooled BF slags: Because Air-cooled BF slags which have a large particle size with porous and uneven surface do not contain harmful substances such as heavy metals and dioxin, they could be used as engineering materials after being crushed and sieved. They may be used as roadbeds, concrete aggregates, general strength structural concrete, nonstructural concrete (e.g., ditch covers, curbs, high-pressure bricks, and water-permeable bricks), and controlled low strength concrete (CLSM).

B. Ground granulated BF slags: Ground granulated BF slags are created from a high-pressure water quenching process. With a main chemical composition of $\mathrm{Ca} 0, \mathrm{SiO}_{2}$, and $\mathrm{Al}_{2} \mathrm{O}_{3}$, they are similar to Portland cement and display hydrate cementation characteristics. When ground into powder, ground granulated BF slags have the potential to exhibit cement-like abilities. By mixing furnace powder with Portland cement, it creates Portland $\mathrm{BF}$ cement, which is the most mature and profitable of all slags. Concerning fine particle BF powder, it can be used as a fill material and blended with concrete to reduce cement slurry pores and increase concrete density, which subsequently enhance concrete durability and quality.

\subsubsection{Basic oxygen furnace slags}

BOF slags display the following physical properties: (1) durability; (2) heat-holding ability; (3) friction properties; (4) anti-flaking ability; (5) stability; and (6) anti-rutting ability [9]. Regarding the recycling and resourcezation of BOF slags, BOF commonly used as raw cement materials, backfill materials, and soil modifiers as well as materials in road surface and base layers, soil improvements agent and water conservancy projects. Japan used BOF slags to reduce, prevent, and control diseases in soil used to grow vegetables, in which it obtained significant and positive results. Germany used fertilizers that contained BOF slags to grow grass and cereals, in which the test results showed that the yield increased by $10 \%-20 \%$ compared with those that used general phosphate fertilizers. In addition, contaminations such as the leaching of heavy metals such as cadmium(Cd) were not observed $[5,10]$.

BOF slags undergo processing procedure such as crushing, magnetic separation, and sieving to become outstanding recycled engineering material-class aggregates. However, the said slags contain free $\mathrm{CaO}$, which are prone to absorbing water or moisture, which induces $\mathrm{CaO}+\mathrm{H}_{2} \mathrm{O} \rightarrow \mathrm{Ca}(\mathrm{OH})_{2}$ reactions. When such reactions occur, $\mathrm{BOF}$ slags expand, dissolve, and turn into powder. Because materials used in roadbeds and road base layers must have an expansion rate of less than $1.5 \%$, for BOF slags to meet this requirement, the splash cooling method may be replaced with the ballast water pocket splitting method during the slag cooling process. The new method allows hot slags to soak in water and stabilize, significantly lowering the expansion rate. 


\subsubsection{Desulfurization slags}

Molten iron created in a BF contains sulfur. To desulfurize molten iron, desulfurization agents are added. This process creates fine particle slags called desulfurization slags. Concerning desulfurization slag resourcezation, they are mostly used as ironmaking materials or low strength concrete. Desulfurization slags that are purified after magnetic separation have a $\mathrm{pH}$ value of 10-12 and may be favorably used as raw cement materials, low strength concrete, cement product fill materials, brick-making materials, coarse aggregate replacements, earth backfill, soil modifier raw materials, and limestone replacements in fired cement clinkers $[11,12]$.

\subsubsection{EAF oxidizing slags}

Oxidizing slags are mostly dark brown in color. Concerning their physical properties, they are durable and wear-resistant and display a low water absorption rate $(1.5 \%-6.8 \%)$, a high specific gravity $(2.5-3.7)$, high particle strength, low abrasion consumption, and high water permeability. In addition, they do not release toxic substances into the environment, are stable in size, and are suitable as pavement materials and coarse aggregate replacements.

Because pavement materials and coarse aggregate replacements normally contain a high iron content, they lead to surface corrosion problems. To solve such problems, magnetic separators may be used to remove the iron content and preserve the overall appearance of the pavement. Oxidizing slags demonstrate favorable durability and anti-rutting ability and are now widely used in the asphalt pavement of major traffic intersections in Taiwan and Singapore $[2,5]$.

\subsubsection{EAF reductive slags}

Reductive slags have a small powder-like appearance and are grayish white in color, because a portion of their $\mathrm{f}-\mathrm{CaO}$ and $\mathrm{MgO}$ will become unstable and expand during reuse. Stabilization treatments must be performed prior to their reuse to enhance their stability [13].

\subsection{Industrial application of different slags}

To achieve waste reuse, the waste must be able to stably serve as alternatives of materials demanded by the market, and the demand for waste materials must be greater than their supply. The use of slags as alternative materials generally takes place in civil engineering-related industries. In this study, the reuse strategies adopted for seven major engineering projects were analyzed. Materials used for such projects are listed as follows: (1) road base layer; (2) asphalt concrete pavement; (3) ready-mixed concrete aggregates; (4) controlled low strength concrete ( CLSM); (5) cement products (concrete bricks, manholes, ditch covers, curbs, and concrete pipes); (6) raw cement material (alternative admixture and raw material); and (7) backfill and landfill.

The concept of cradle to cradle was implemented, in which what the slags could serve as replacements of were determined according to their properties. This allowed the slags to be recycled and reprocessed accordingly and made into valuable industrial nutrients to be used in closed industrial circulations. Table 1 shows Taiwan's annual output of the various types of slags. According to the table, the demands for the slags as alternatives of materials for the seven major engineering projects all exceed their supply, meeting the cradle-to-cradle industrial metabolism criterion, allowing raw materials to maintain their original properties when introduced to different circulations, achieving the goal of upcycling, and satisfying the principle of waste is food. However, some of the related technologies remained immature and are to be improved as new industrial technologies are made available the future. 
Table 1. Taiwan's annual output of the various types of slags $[2,13,14]$

\begin{tabular}{|c|c|c|c|c|c|}
\hline \multirow{2}{*}{$\begin{array}{l}\text { Slag } \\
\text { type }\end{array}$} & \multirow{2}{*}{$\begin{array}{l}\text { Byproduct(s) created and the } \\
\text { steelmaking process involved }\end{array}$} & \multirow{2}{*}{$\begin{array}{l}\text { Annual output } \\
\text { (unit: 10,000 } \\
\text { tonnes) }\end{array}$} & \multirow{2}{*}{$\begin{array}{l}\text { Mainly used as a } \\
\text { replacement of }\end{array}$} & $\begin{array}{l}\text { materials } \\
\text { demanded }\end{array}$ & \multirow{2}{*}{$\begin{array}{l}\text { Usage restriction } \\
\text { assessment }\end{array}$} \\
\hline & & & & $\begin{array}{l}\text { (unit: } 10,000 \\
\text { tonnes/year) }\end{array}$ & \\
\hline 1 & $\begin{array}{l}\text { BF slags created from the } \\
\text { continuous steelmaking process }\end{array}$ & 400 & & & \\
\hline \multirow{5}{*}{1.1} & \multirow{5}{*}{$\begin{array}{l}\text { Air-cooled BF slags :account for } \\
\text { approximately } 5 \% \text { of all BF slags }\end{array}$} & \multirow{5}{*}{20} & 1.Road base layer & $150^{1}: *$ & \\
\hline & & & $\begin{array}{l}\text { 2.Asphalt concrete } \\
\text { pavement }\end{array}$ & $600^{2}$ & \\
\hline & & & $\begin{array}{l}\text { 3.Ready-mixed concrete } \\
\text { aggregate }\end{array}$ & $9250^{3}$ & \\
\hline & & & $\begin{array}{l}\text { 4.Controlled low } \\
\text { strength concrete }\end{array}$ & $250^{4}$ & \\
\hline & & & 5.Cement products & $200^{5}$ & \\
\hline 1.2 & $\begin{array}{l}\text { Ground granulated BF slags: } \\
\text { account for approximately } 95 \% \text { of } \\
\text { all BF slags }\end{array}$ & 380 & 1. Raw cement materials & $1200^{6}$ & \\
\hline \multirow{8}{*}{2} & \multirow{8}{*}{$\begin{array}{l}\text { BOF slags created from the } \\
\text { continuous steelmaking process }\end{array}$} & \multirow{8}{*}{150} & 1.Road base layer & $150^{1}$ & $\begin{array}{l}\text { Stabilization } \\
\text { treatment required }\end{array}$ \\
\hline & & & $\begin{array}{l}\text { 2.Asphalt concrete } \\
\text { pavement }\end{array}$ & $600^{2}$ & $\begin{array}{l}\text { Stabilization } \\
\text { treatment required }\end{array}$ \\
\hline & & & $\begin{array}{l}\text { 3.Ready-mixed concrete } \\
\text { aggregate }\end{array}$ & $9250^{3}$ & \\
\hline & & & $\begin{array}{l}\text { 4. Controlled low } \\
\text { strength concrete }\end{array}$ & $250^{4}$ & \\
\hline & & & 5.Cement products & $200^{5}$ & \\
\hline & & & 6.Raw cement materials & $1200^{6}$ & \\
\hline & & & 7.Backfill and landfill & $460^{7}$ & \\
\hline & & & 8.Stell slag powder & & \\
\hline \multirow{5}{*}{3} & \multirow{5}{*}{$\begin{array}{l}\text { Desulfurization slags created } \\
\text { from the continuous steelmaking } \\
\text { process }\end{array}$} & \multirow{5}{*}{40} & 1.Road base layer & $150^{1}$ & \\
\hline & & & $\begin{array}{l}\text { 2.Asphalt concrete } \\
\text { pavement }\end{array}$ & $600^{2}$ & \\
\hline & & & $\begin{array}{l}\text { 3.Ready-mixed concrete } \\
\text { aggregate }\end{array}$ & $9250^{3}$ & \\
\hline & & & $\begin{array}{l}\text { 4. Controlled low } \\
\text { strength concrete }\end{array}$ & $250^{4}$ & \\
\hline & & & 5.Cement products & $200^{5}$ & \\
\hline
\end{tabular}




\begin{tabular}{|c|c|c|c|c|c|}
\hline & & & 6. Raw cement materials & $1200^{6}$ & \\
\hline & & & 7.Backfill and landfill & $460^{7}$ & \\
\hline \multirow{6}{*}{4} & \multirow{6}{*}{$\begin{array}{l}\text { EAF oxidizing slags created from } \\
\text { the EF steelmaking process }\end{array}$} & \multirow{6}{*}{140} & 1.Road base layer & $150^{1}:$ & \\
\hline & & & $\begin{array}{l}\text { 2.Asphalt concrete } \\
\text { pavement }\end{array}$ & $600^{2}$ & $\begin{array}{l}\text { Improve corrosion } \\
\text { by removing iron } \\
\text { using a magnetic } \\
\text { separator }\end{array}$ \\
\hline & & & $\begin{array}{l}\text { 3.Ready-mixed concrete } \\
\text { aggregate }\end{array}$ & $9250^{3}$ & $\begin{array}{l}\text { Improve corrosion } \\
\text { by removing iron } \\
\text { using a magnetic } \\
\text { separator }\end{array}$ \\
\hline & & & $\begin{array}{l}\text { 4.Conrolled low } \\
\text { strength concrete }\end{array}$ & $250^{4}$ & \\
\hline & & & 5.Cement products & $200^{5}$ & \\
\hline & & & 6.Backfill and landfill & $460^{7}$ & \\
\hline \multirow{2}{*}{5} & \multirow{2}{*}{$\begin{array}{l}\text { EAF reductive slags created from } \\
\text { the EAF steelmaking process }\end{array}$} & \multirow{2}{*}{40} & 1. Cement products & $200^{5}$ & $\begin{array}{l}\text { Stabilization } \\
\text { treatment required }\end{array}$ \\
\hline & & & $\begin{array}{l}\text { 2.RAW cement } \\
\text { materials }\end{array}$ & $1200^{6}$ & $\begin{array}{l}\text { Stabilization } \\
\text { treatment required }\end{array}$ \\
\hline
\end{tabular}

$*: X^{Y} \rightarrow X$ : the demand for materials that the slags can be a replacement of; $Y:$ the replacement path and number

\section{Conclusion}

1. Prior to reusing slags, their assessments must be made to identify their properties. Next, appropriate usage options must be determined accordingly. Slags created from the EAF oxidation stage and those created from the reduction stage show considerably different chemical compositions and characteristics. Because reductive slags and BOF slags contain relatively more free $\mathrm{CaO}$ and $\mathrm{MgO}$, they create gradual expansion problems when used in backfill or asphalt pavement. Thus, prior to such usage, stabilization treatments must be performed. Concerning oxidizing slags, because they have a high iron content, which leads to surface corrosion, magnetic separators must be used to remove the iron content and improve corrosion.

2. The annual outputs of slags are relatively constant. To prevent unauthorized burying of slags, their disposal locations must be transparent and their disposal must be managed by designated units. In addition, complete technologies must be used jointly to facilitate waste resourcezation. Furthermore, standards and verification systems must be enforced according to government policies to allow the professional industry, the government, and the academic industry to promote cradle to cradle together.
3. To allow slags to be used as recycled resources, diversified strategies should be devised. Various aspects should be taken into account, such as slags displaying chemical properties similar to cement products and physical properties similar to coarse and fine aggregates used in concrete, the large demand for civil engineering materials, and the diversified applications of civil engineering materials. On the basis of the slag properties, different, most appropriate reuse options should be formulated and accurate slag yields and the total demand for slags as replacement materials should be obtained. Finally, the demand for waste materials being greater than their supply should be confirmed to ensure sustainable usage and achieve stable slag elimination.

4. The ultimate goal of slag resourcezation is to implement the cradle to cradle concept, achieve upcycling, reuse waste, maintain waste in the industrial metabolism, and realize sustainable economic, social, and environmental balance.

\section{References}

1. P.T. Teo, A.A. Semana, P Basub, and N.M Sharif, "Characterization of EAF Steel Slag Waste: The Potential Green Resource for Ceramic Tile Production". Procedia Chemistry (2016), P.842-846

2. Taiwan Construction Research Institute. "An 
Introduction to the Properties of Steelmaking Slags and Related Management Laws, Regulations, Standards, and Guidelines." Seminar and Collected Papers on the Optimal Method for Achieving Steelmaking Slag Resourcezation and Application, Management, and Control Strategies for Concrete Engineering. (2016)

3. W. McDonough M. Braungart, Cradle to Cradle: Remaking The Way We Make Things. New York, North Point Press, 2002

4. S.Z. Chang, "Physical and Chemical Properties of Electric Arc Furnace Oxidizing Slags and Mortars." Master's Thesis. Institute of Construction Management, Chung Hua University; Hsinchu. (2015)

5. CHC Resources. Access date 7 Feb. 2017; available from http://www.chc.com.tw/product_2.html

6. M. Braungart, W. McDonough, The Upcycle: Beyond Sustainability-Designing For Abundance. New York, North Point Press, 2013

7. MBDC LLC. Cradle to Cradle CertifiedCM Product Standard Version 3, Access date 7 Feb. 2017; from http://www.c2ccertified.org/images/uploads/C2CCert ified_Product_Standard_V3_121112.pdf

8. M.E. Toxopeusa, B.L.A de Koeijera, A.G.G.H. Meijb. Cradle to Cradle: Effective Vision vs. Efficient Practice? The 22th CIRP International Conference on Lifecycle Engineering, Sydney Australia.Heidelberg, Springer, 2015 Procedia CIRP 29 P.384 - 389, 2015
9. D. Huang, "The Investigation of Replacing Natural Aggregates with BOF Steel Slag which Effecting VMA Characteristics of Hot Mix Asphalt" Master's Thesis, National Central University; Zhongli, 2008.

10. X.R. Chen, and G.Z. Chang-jian, "The Effect of Basic Oxygen Furnace Slags on Environmental Compatibility." 2011 Seminar and Collected Papers on the Use of Basic Oxygen Furnace Slags in Asphalt Concrete Pavement. (2011)

11. S. K. Kawatra, S. J. Ripke, "Pelletizing steel mill desulfurization slag", International Journal of Mineral Processing, vol. 65. Elsevier, Amsterdam, pp.165-172, 2002

12. W.T. Guo, and S.S. Chen, "The Feasibility of Defulsurzation Slag Used as Aggregates for Asphalt Concrete". Journal of the Chinese Institute of Mining \& Metallurgical Engineers, Vol. 54, No.4, pp. 40-50, 2010.

13. S.W. Tseng. "Assessing the Use of Electric Arc Furnace Reductive Slags as Controlled Low Strength Materials and Their Stabilization Performance." Master's Thesis. National Central University, Zhongli. 2012

14. J.C. Xing "Utilization of the Electric Arc Furnace Oxidizing Slag as Microstructure Materials." Master's Thesis (2014). Institute of Materials and Mineral Resources Engineering, National Taipei University of Technology: Taipei, 2014 